\title{
Efforts to Improve Integrated Services Post (POSYANDU) Cadre Skills in Stunting Detection Through Cadre Training
}

\author{
Fitria Prabandaria), Sumarni, Suryati, Nadya Alifah Putri, Erika, and \\ Septianingsih
}

Universitas Muhammadiyah Gombong, Gombong, Indonesia

a)Corresponding author: Fitriaprabandari30@gmail.com

\begin{abstract}
The Integrated Services Post (Posyandu) program is good enough to monitor children's growth and development, but with the Covid-19 pandemic, Posyandu activities have been temporarily suspended face-to-face, thus monitoring the development and growth of toddlers, which is usually carried out by cadres at Posyandu, is also hampered. Therefore, efforts are needed to improve the skills of Posyandu cadres to detect stunting within the scope of the Dasawisma as assistance to mothers of toddlers both online and in face-to-face meetings while still paying attention to health protocols to prevent the spread of the Covid-19 virus. The purpose of this activity is to improve the skills of Posyandu cadres in stunting detection through cadre training. The method of this activity is the preparation of coordination with partners, coordination with village midwives and cadres, determining a joint schedule, making media booklets and questionnaires, then continuing with the implementation of activities starting with pretest, training, and evaluation with posttest, and assistance for stunting detection activities. The results of this community service are that after training Posyandu cadres experienced an increase in knowledge and skills on stunting detection, as many as 26 Posyandu in Karangkelsem Village received a grant for stamping scales and height measuring devices, and the skills of Posyandu cadres in detecting stunting increased. This community service concludes that training can improve the knowledge and skills of Posyandu cadres in detecting stunting during the Covid-19 pandemic.
\end{abstract}

Keywords: Training, stunting, Posyandu, cadre

\section{INTRODUCTION}

The role of parents, especially mothers, is very important in fulfilling children's nutrition because children need parental attention and support in facing very rapid growth and development. To get good nutrition, it is necessary to have good nutritional knowledge from parents to provide a balanced menu of choices. A person's level of nutritional knowledge affects attitudes and behavior in food selection. Stunting is not only caused by one factor but is caused by many factors that are interconnected with one another. Among the factors that influence the incidence of stunting, parenting plays an important role in the occurrence of growth disorders in children. Poor parenting can cause nutritional problems in the community.

Stunting is defined as a short or very short body condition based on an index of Body Length for Age (PB/U) or Height for Age (TB/U) with a threshold (z-score) between -3 SD to < -2 Elementary School (Kemenkes RI, 2019). Stunting in children is a long-term result of chronic consumption of poor quality diets combined with morbidity, infectious diseases, and environmental problems. Stunting children are at risk of increased morbidity and mortality, stunted motor and mental development, decreased intellectual and productivity, increased risk of degenerative diseases, obesity, and are more susceptible to infectious diseases. Stunting in elementary school children is a manifestation of stunting in toddlers who experience failure to catch up with growth, nutritional deficiencies in the long term, and the presence of infectious diseases (Semba et al, 2008).

Monitoring the nutritional status of children in Indonesia is usually carried out in Posyandu activities. Posyandu as a forum for community participation, which organizes a service system for meeting basic needs, improving human quality, empirically has been able to equalize health services. These activities include immunization services, community nutrition education, and 
maternal and child health services. (http://www.indonesianpublichealth.com/2020). Cadres are also expected to play an active role and be able to become a source of information as well as a supporter and motivator for the community (Yuliani et al., 2018).

The nutritional status of toddlers is an important thing that every parent must know. Most of the incidence of malnutrition can be avoided if you have enough knowledge about how to maintain nutrition and manage children's food. When the baby enters the age of 6 months and over, some nutritional elements such as carbohydrates, protein, and some vitamins and minerals contained in breast milk or formula are no longer sufficient. Therefore, from the age of 6 months, infants other than breast milk are given complementary foods (MPASI) so that the nutritional needs of infants/children are met. In giving MPASI, it is necessary to pay attention to the timing of giving MPASI, the frequency of servings, the selection of food ingredients, how to make and how to give it (Mufida, 2015).

Before the Covid-19 pandemic, the Posyandu program was good enough to monitor children's growth and development, but with the Covid-19 pandemic, Posyandu activities were temporarily suspended face-to-face, thus monitoring the development and growth of toddlers, which is usually carried out by cadres at Posyandu, was also hampered. . Therefore, it is necessary to assist mothers of toddlers both online and face-to-face meetings while still paying attention to health protocols to prevent the spread of the Coronavirus. The purpose of monitoring is so that mothers of toddlers know and are aware of the causes of stunting.

Monitoring of toddlers by cadres is a form of active community participation where cadres as companions carry out ongoing interactions with toddlers. To avoid crowds that will increase the risk of transmission of the covid-19 virus, it should be done in a limited manner and continue to implement the health protocol, this can be done by limiting the scope of Dasawisma only, but not every Dasawisma has Posyandu cadres, so there needs to be training for cadres who will monitor growth and development of toddlers in every Dasawisma. Some of the things provided during monitoring include monitoring height and weight as well as BMI and Z-score, introducing signs of stunting, how to prevent it, and management if you are forced to carry out examinations at health service facilities so that the hope is to achieve optimal health for toddlers during the pandemic. covid 19.

Karangklesem Village is located in the South Purwokerto Subdistrict, Banyumas Regency, there are 13 RW, 69 RT, and 26 Posyandu for toddlers with each Posyandu having 5 cadres so that the total number of cadres in Karangklesem is 130 cadres. namely a total of 25 cadres. In December 2020 the number of toddlers in Karangklesem was 676 toddlers (343 boys, 333 girls), and 11 stunting cases were found. During the pandemic, Posyandu activities were stopped because to avoid crowds, health workers and Posyandu cadres had difficulty collecting data on toddlers, as well as not all parents of toddlers routinely reporting their toddler data to health workers or Posyandu cadres, so cadre training for each Dasawisma is needed to make it easier monitoring of toddlers without having to crowd at the toddler Posyandu so that the risk of Covid-19 transmission is reduced and toddlers are still properly monitored.

\section{MATERIALS AND METHODS}

Community service activities through training and assistance programs for Posyandu cadres in detecting stunting in Karangklesem Village are expected in the long term to provide benefits for cadres and mothers of toddlers so that they can continue to carry out Posyandu activities during the Covid-19 pandemic. The community service activities are divided into four stages which are designed to be implemented using an approach that involves partner participation as presented in table 1 below:

1. Preparation

a. Partners are actively involved in arranging activity schedules and providing a place for activities, namely at the village hall Karangkelsem and coordinating with village midwives in the South Purwokerto Health Center area. 
b. Partners are actively involved in expressing opinions and conveying the problems they face related to the difficulties in implementing Posyandu during the pandemic and not all Posyandu are available with stamping scales and height measuring devices that can be carried everywhere.

2. Implementation of activities

a. Cadres fill out pre-test sheets

b. Cadres are actively involved in the training held

c. Cadres fill out the post-test sheet

3. Evaluation

Cadres practice the skills of measuring height and weight to the house of mothers of toddlers to detect stunting by bringing scales and height measuring devices while videotaping activities and sending them to service providers as evidence of activities.

4. Follow-up plans

After cadres have participated in all activities, then assistance is provided through online media for discussions regarding matters that still need to be asked regarding stunting detection and Posyandu activities during the Covid-19 pandemic.

\section{RESULTS}

The Posyandu cadres who participated in this community service activity consisted of 26 cadres representing 26 Posyandu in Karangklesem Village.

The results achieved in this community service program include:

1. Increased knowledge of partners about stunting which is presented in table 1

2. Posyandu cadres receive a grant of scales and height measuring devices which will be used for Posyandu activities in each Posyandu (Figure 1)

3. Documentation of the results of the activities of Posyandu cadres who are weighing and measuring height as an effort to detect stunting at the home of mothers under five by implementing a health protocol (Figure 2)

\section{DISCUSSION}

In the first preparatory stage, preparation of the activity process includes coordination with partners, coordination with village midwives and cadres, determination of joint schedules, preparation of media booklets and questionnaires. At the preparation stage, this was done by meeting partners at the Karangklesem Village office. Making booklets and questionnaires involves the entire community service team. After getting an agreement on the schedule and place for the training, partners will help invite Posyandu cadres to attend training events while still implementing health protocols.

In the second stage, service activities were carried out covering several activities, namely: before participating in cadre training, first filling out a pretest sheet, followed by core activities, namely training with material on stunting and techniques for implementing Posyandu activities within the Dasawisma scope of training activities for approximately 4 hours, after completion of cadre training fill out the posttest sheet to measure the increase in knowledge, the posttest results show an increase in knowledge of Posyandu cadres between the pre-test and post-test scores. For the pretest value, the average evaluation result or mean is 56.15 , while for the post-test value, the average value is 89.12 . Due to the average value of the evaluation results on the pre-test 56.15 < post-test 89.12 , it means that descriptively there is a difference in the average value of the evaluation between the pretest and post-test results (table 2).

After the training is complete, the next stage is the distribution of a grant for weights and height measuring devices that will be used by cadres in Posyandu duties during the pandemic, namely monitoring the health of toddlers by trained cadres to mothers of toddlers in the Dasawisma scope, this activity takes approximately 6 hours, namely, Posyandu cadres previously asked permission from the parents of toddlers to directly measure the length (PB) / height (TB) and weight (BB) of toddlers near their homes as well as filling out KMS and 
monitoring tables that have been provided, and of course implementing health protocols when meeting in person. The activity was monitored by the community service team through a WhatsApp video call. then provide feedback regarding the implementation. With training representatives from each Posyandu

\section{CONCLUSIONS AND RECOMMENDATIONS}

The community service team at the University of Muhammadiyah Gombong, the Midwifery study program, has completed training for Posyandu cadres in Karangklesem Village, South Purwokerto District, Banyumas Regency. These activities include planning, training, and evaluation. The results of this training include increasing the knowledge and skills of Posyandu cadres in stunting detection and the availability of stamping scales and height measuring devices for each Posyandu and can be brought to visit mothers of toddlers during the Covid19 pandemic.

After this community service activity is carried out, it is hoped that the cadre representatives of each Posyandu will convey the results of their training to other Posyandu cadres in the same Posyandu so that Posyandu activities can still be carried out even during a pandemic and stunting can be prevented early.

\section{ACKNOWLEDGMENTS}

Thank you to:

1. Research and Community Service Institute (LPPM) of Universitas Muhammadiyah Gombong which has provided the opportunity and funded this community service activity so that it runs smoothly.

2. Village Karangkelsem which has given permission for training activities and provides a training place and helps with all needs during the training.

3. Posyandu cadres for toddlers who have taken the time to attend the training well and smoothly

\section{REFERENCES}

Depkes RI. 2006. Pedoman Umum Pengelolaan Posyandu. Jakarta: Depkes RI. French R. 2011. Organization Behavior. Wiley. 689 p.

Kemenkes RI. 2018. Hasil Pemantauan Status Gizi (PSG). Direktorat Jenderal Kesehatan Masyarakat: Jakarta.

Kemenkes RI. 2015. Pelatihan dan Modul Pelatihan Posyandu. Jakarta: Kemenkes RI

Kemenkes RI. 2019. Infodatin: Situasi Balita Pendek. Pusat Data dan Informasi Kementerian Kesehatan RI, 2019-September. 3. doi: 10.1109/ CSCMP45713. 2019. 8976568.

Lisnawati L. 2015. Analisis faktor Kinerja Kader dalam Upaya Revitalisasi Posyandu. J Bidan "Midwife J;1(2):345.

Mufida, L., Widyaningsih, T. D., \& Maligan, J. M. 2015. Prinsip Dasar Makanan Pendamping Air Susu lbu (MpASI) untuk Bayi 6-24 bulan: Kajian Pustaka Basic Principles of Complementary Feeding for Infant 6-24 Months: A Review, 3(4), 1646-651.

Notoatmodjo, S. 2010. Ilmu Perilaku Kesehatan. Jakarta. Rineka Cipta Pribadi. B. A. 2009. Model Desain Sistem Pembelajaran. Jakarta: Penerbit Dian Rakyat.

Semba RD, de Pee S, Sun K, Sari M, Akhter N, Bloem MW. 2008. Effect of parental formal education on risk of child stuntpv7iuing in Indonesia and Bangladesh: a cross sectional study. The Lancet Article; 371:322-8.

Yuliani, E. et al. 2018. Pelatihan Kader Kesehatan Deteksi Dini Stunting Pada Balita Di Desa Betteng: Health Cadre Training About Early Detection Of Stunting Toddler In Betteng Village. Jurnal Pengabdian Masyarakat Kesehatan, 4(2), pp. 41-4 


\section{APPENDIX}

Table 1. Average Pretest and Posttest

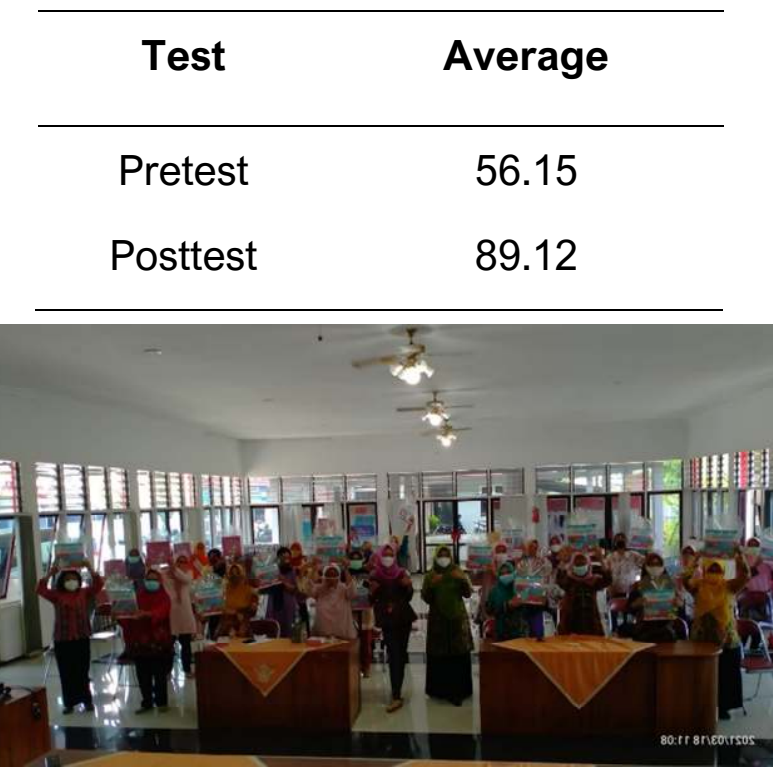

Figure 1. Submission of Stepping Scales and Height Measuring Devices for 26 Posyandu

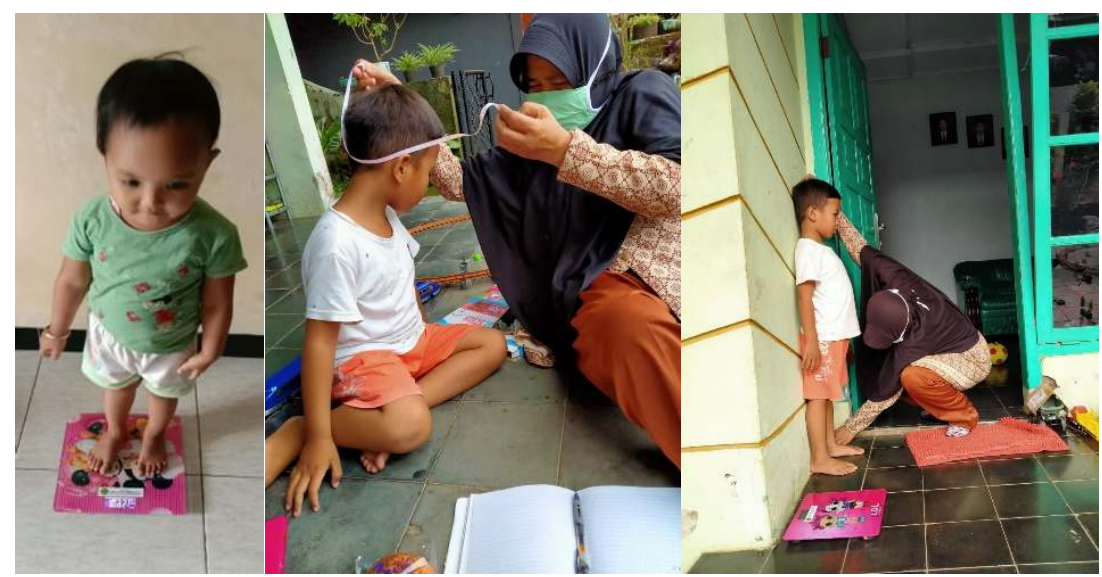

Figure 2. The results of the activities of Posyandu cadres who are weighing and measuring height as an effort to detect stunting at the home of mothers of toddlers 